УдК: 393(477.8):2:718(091)

\title{
Burial motives in the studies of Rev. M. Zubrytskyi
}

\author{
M. Tygai \\ Vasyl Stefanyk Precarpation National University \\ tmikola69@gmail.com
}

Key words: family ritualism, funeral, deceased, lamenting, the Boykos region, Reverend M.Zubrytskui.

\begin{abstract}
This article deals with the issue of the burial motives in the Boykos ethnographic groups, which were analysed on the basis of the Reverend M.Zubrytskyi scientific work. It highlights the stages of the burial process and the way its set customs and traditions are observed; in particular, the way its unalienable elements and attributes are used. The first stage is preburial - it is caused by people's beliefs and superstitions, dreams which may be omens of the future death; the second stage is the burial itself, which is connected with the death itself and the funeral of the deceased; the third stage is after-burial, which is characterised by observing certain prohibitions and warnings. The article defines the way local Boykos people imagined and perceived death, heaven and hell. It also provides the system of restrictions and prohibitions for people, which are to be followed after death of a close relative. The scientist noted down interesting observations concerning lamenting, its customary appliance and meaning. The main conclusion of the article is proving the existence of archaic elements of the burial motives among the population of the Starosambir and Turkiv regions.
\end{abstract}

\section{Поховальні мотиви у дослідженнях о. М. Зубрицького}

\author{
M. I. Тугай \\ Прикарпатський національний університет імені В. Стефаника
}

Ключові слова: родинно-сімей на обрядовість, похорон, покійник, голосіння, «горячина», Бойківщина, о. М. Зубрицький.
У статті на основі вивчення наукової спадщини о. М. Зубрицького проаналізовано поховальні мотиви бойківської етнографічної групи. Висвітлено етапність поховального процесу та дотримання усталених звичаїв і обрядів із використанням його невід'ємних елементів та атрибутів. Окреслено уявлення у місцевого населення Бойківщини про смерть, рай та пекло. Описано систему заборон та обмежень для людей після смерті близького родича. Основний висновок статті полягає у констатації наявності архаїчних елементів поховальних мотивів серед населення Старосамбірщини та Турківщини.
Burial motives comprise a unique part of the family ritualism in the spiritual culture of every ethnographic group of Ukrainians. These burial acts occupy the key place in people's lives. Burial ritualism remains the most conservative one, compared to other family rituals, customs and traditions. This might be explained by a constant set of archaic elements and attributes, which have not undergone changes for a significant period of time. This kind of conservatism is particularly characteristic to the burial process of Ukrainian highlanders, including the Boykos.

Burial rituals and customs remain among the research objects of Ukrainian and foreign scientists, ethnographers, folklore scientists. Reverend M.Zubrytskyi, the clergyman of the village Mshanets, a member of the Taras Shevchenko Scientific Society, a prominent Ukrainian ethnographer, can be listed among these people. He was the one who brought up the given issue to the light of research more than 100 years ago. It's worth stating, that the problem of the burial motives of Boykos people comprised just a single aspect of the ethnographic scientific interests of the researcher. Burial customary actions, their elements and attributes were of a significant interest for the researcher, who was a priest at the same time, therefore he was able to witness and participate in lots of authentic customary actions, which were connected with the burial process in the Western Boykos region.

The given material from the sphere of source criticism is valuable and important in terms of future research in the field of folklore and ethnography, in particular for the detailed study of the spiritual culture of the Boykos ethnographic group.

In modern Ukrainian historiography the prob- 
lem of the family ritualism is quite important and attracts enough scientific attention. Some of the scientific interest is due to the study of personalities who were doing the scientific research of the given problem, the burial process in particular. At the same time, in modern Ukrainian ethnology, the professional research and study of the burial motives in the works by Reverend M.Zubrytskyi has not been made yet. However, such modern Ukrainian scientists as R.Kyrchiv [1], S.Gvozdevych [2], F.Sysyn [3], G. Sokil [4], 0.Drogobytska [5], G.Demian [6] highlighted certain aspects of the scientific and research activity of the given ethnologist as well as burial motives in his works in their scientific works.

The Canadian scientist F.Sysyn, in particular, pointed out that M.Zubrytskyi had made his own research of the burial customs, and it included drawings of coffins, as well as provided real lamenting and rituals of one of the most important events in the life cycle of a person, as peasants saw and treated it [3, p.39-40]. Ukrainian scientist R.Kyrchiv pointed out that in the given works the ethnographer noted down funeral customs, rituals and superstitions, which were connected with death [1, p. 65]. Having analysed the main work of the ethnographer on the given topic, another Ukrainian scientist S.Gvozdevych summed up that it had been compiled clearly and logically, and it provided information on how peasants were preparing for death and the way they acted when death would come [2, p. 395]. Ethnographer G.Sokil stated that material, which had been published by Reverend M.Zybrytskyi, enclosed different stages of the rituals under study, it could be divided into separate parts, and it included interesting observations on lamenting, when and how it was used [4, p. 400].

The objective of the article is to analyse burial motives in the works of the Ukrainian ethnographer Reverend M.Zubrytskyi. The object of the article is burial rituals and particular motives connected with them.

Reverend M. Zubrytskyi is a famous Ukrainian ethnographer, civil and cultural activist. This scientist devoted his life to education and enlightenment of the residents of the village Mshanets and other places on the territory of the Western Boykos region. He spent a lot of time gathering ethnographic and folklore material, systemising it in order to publish it later in scientific magazines of that time. A lot of material he managed to gather interacting with local residents, while some of it is based on his personal observations.

The ethnographer paid a great deal of attention to source and material gathering in questions of burial rituals and customs. This was done following the advice from a Ukrainian ethnographer V.Gnatiuk, who wrote in his letter (dated November, 17, 1910) that Reverend M.Zubrytskyi «should do his best to complete a full description of a Boykos funeral» [6, p. 301]. The latter one managed to gather a lot of relevant ethnographic material in villages Kindrative and Lyp'ia in the Turkiv region and villages Mshanets, Mykhnivtsi, Bystre, Tykha, Vypiv, Chorna in the Starosambir region. These materials were generalized, analysed and presented in a published work «Burial customs and traditions in Mshantsy and nearby villages of the Starosambir and Tyrchan districts» [7], as well as in the work «Myths and believes» [8].

In his scientific articles Reverend M.Zubrytskyi clearly defined three stages of the burial process: the first one is pre-burial, the second one is funeral which includes burial itself, and the third one is after-burial.

On the first stage of the burial process Reverand M.Zubrytskyi defines people's tales and stories connected with the upcoming death and their perception of the afterlife world. According to what they told the scientist, he noted their beliefs in afterlife (heaven and hell), which was closely connected with the religious upbringing of people. The ethnographer wrote down the way Boykos imagined the Heaven and the Hell and the ways people get there. According to their stories, people believed that if a person dies when it is customary to say or chant «Christ has arisen», the deceased will go to heavens? Because «the hell is locked, but the Heaven is open» [7, p. 218], more than that according to the ethnographer «it is time to die only for poor and cripples» [9, p. 45].

He also wrote down a story according to which a deceased mother «was calling» her child to hell, but the child answered «Go thou, my mother, where they have let you, if it is hell what you have deserved» $[7$, p. 218].

There existed a whole system of folk customs and superstitions connected with death. In his work «Burial customs...» Rev.M.Zubrytskyi wrote that «death has a rake, a scythe, a spade and a saw». People believed in a certain type of death, which could be easy and hard. According to the people's beliefs, if a man died an easy death - it was brought forth by «a scythe», if the death was hard - it was caused with «a saw» $[7$, p. 212]. In understanding of local people death was closely connected and explained by the belief that «if people didn't die, they would soon hold skies on their shoulders» [7, p. 211]. 
In particular these beliefs might be traced in a construction sphere. A builder was often associated with a person, who would have certain connection to death. Following the tales of local people, death could be foretold observing activities of a carpenter («a master»). If he started his construction of a house «and a split from a bast falls to the ground, there will be a dead person soon», and on the contrary, if it falls the opposite side, "the side of a tree», - one should wait for a wedding. Also they said, if it falls woutside, there will be a dead man soon, and if it falls inside - one should wait for a wedding» [7, p. 211]. There were also similar beliefs: in a wall gave a crack near the table, the master of the house might die, if it happened near the stove, the mistress of the house might die, if the wall gave a crack in between windows, «lads» would die, on the contrary, if it happened near the shelves - «girls» would die [7, p. 211]. One of such omens proved to be true in the family of Nykolai Lesiovyi from the village Mshanets; a wall in his house cracked twice on the Christmas Eve and he said: «We will have something new!» and later his wife died, who was near 30 [7, p. 211].

A particular variant of upcoming death prediction was hidden in certain dreams and their perception. The ethnographer described a story of one of the resident of the village Mshanets in great detail: «if one dreams that they go along the stream and a bank of the river hits them, there should be someone dead soon; if you dream of geese, people say, there would be death soon: if one dreams of a wedding, or a oxen which plough the ground, this is a sign of a soon death; if one sees fabric being woven, they say, death would come soon; if a cabbage grows on a cabbage in clay, and its size is like a fist, but the top is dry and withering, these signs mean a deceased». He pointed out that dreams about cattle, chicken clucking in the evening, a mole, which had dug a big molehill all meant the same bad news [7, p. 211].

Also there existed a superstition, which was connected with wedding ritualism and was used when someone wanted to do something bad to others. According to folk beliefs, written down by M.Zubrytskyi, if a newly-wed daughter-in-law comes to her husband's house, stands of the threshold and hops, someone from the elder members of the family will die. Hopping on the threshold she should repeat: «Is there a hole where a father and a mother could be hidden?». One of such occasions was written down by the ethnographer in the village Lypie of the Turkiv region, where a newly-wed girl said «Is there a place near the stove, where a father and a mother could be hidden?». Soon afterwards both of them died and the girl was made to leave the house [7, p. 211].

Therefore, Reverend M.Zubrytskyi depicted death with the help of household objects, according to those people associated easy and difficult death with them. Omens of the upcoming death were an inevitable part of the people's beliefs which were connected with the appearance of the deceased, and this all was connected with numerous signs, beliefs and dreams.

The appearance of a dead man constituted a separate element of the burial ritualism, and it symbolized the beginning of the second stage of the burial process. Usually there existed the whole system of the actions to be performed on the dead body, they were so-called traditions customary actions. If there appeared a dead body in the house, they would send somebody to inform their neighbours, so they would know there was a deceased in the house. This kind of words of mouth was spread in the village Mshantsi, but at the same time, in the villages Mykhnivtsi, Bystre and Chorna, a wife, a mother or a girl would go to nighbours, and «there they would lament and let the neigbours know, that they had a dead body in their house» [7, p. 212].

The next ritual action was the washing of the dead body. When there was a deceased in the house, he was washed only by those, who had lived with him, while «the elderly were washed by non-relatives and neighbours» [7, p. 212]. After that they would sweep everything away in «a bucket», then put that away and throw into water. The straw, on which the deceased lied, was also to be put into the water, but if the master of the house had already had a place, where no one would go, then «it was thrown there, in a corner, in some stinging nettle, where no cattle could eat it, otherwise the cattle soon would be toothless» [7, p. 212]. At the time, the water, which was used to was the deceased, was considers «unclean» and very harmful for anyone, who would step on the place, where it had been poured [2, p. 395].

Therefore, the first stage of the burial ritualism was connected with informing the residents of the village about the fact, that someone had died, and with the washing of the dead body. Both rituals were performed according to certain rules, which were also closely followed during the funeral.

After the ritual of washing, there started the ritual of dressing the deceased up. Reverend M.Zubrytskyi described in great detail what kind of clothes it was and what the process looked like. A married man («a master») would be dressed in a shirt, «which was fastened without buttons and clasps, the shirt was held around the waist with a kind of a belt or a 
shawl». They would put a woolen hat of the head of the man, and linen trousers on the feet [7, p. 213]. A daughter-in-law would be dressed in a shirt, fastened with ribbons, a while skirt, a white apron and a ribbon on the waist. As the ethnographer wrote down, at first, the ribbon had been black, but later it changed for red, which could be could be bought in a church [7, p. 213]. They would also put a shawl on her head, and a cross on her chest. Also put used to dress the deceased woman in coral bead sand and glass bead decorations, and a shawl would cover her cheekbones. The scientist pointed out that glass beads and a cross became a part of the funeral clothes much later [7, p. 213]. A young man would be dressed in all the new clothes, fastened with a belt, they would also put «an end of a red shawl that would follow the length of the body» behind the belt. People would out a hat near the head, and «sow a periwinkle wreath» to it. A young unmarried girl would be dressed in all the new clothes, her hair would be brushed but not plaid, it would lay loose on her shoulders. Her head would be covered with a shawl, and over it they would put «a red ribbon, with its ends falling loose on her shoulders: on the top of her head there would be a periwinkle wreath, sown to the shawl, and aroundher neck there would be another shawl» [7, p. 213]. A common feature, which could be traced in all the funerals, was putting stockings on the legs of the deceased. The ethnographer summed up that «each body was covered with a piece of white, home-made cloth» [7, p. 213].

According to the notes made by Rev. M.Zubrytskyi, one can understand that bodies of the deceased were dressed differently, taking into account their age ad gender peculiarities, therefore, one can trace both similar and different features in their dress customs.

The next action, which had to be done by the relatives of the deceased, was to place a coffin with the dead body in the house correctly. In the village, where the ethnographer was born, which was called Kindrative in the Turkiv region, a coffin with a body of a small child was usually put on a table with the head of the child directed at the window $[8, p$. $360]$. On the contrary, elderly people were layed on a bench «covered with a white cloth, and there they would place a fully dressed body, with the head directed at the table, and feet directed at the door» [9, c. 214].

The ethnographer emphasized that a person, who was responsible for preparing and organizing of a funeral, was the busiest. His duties included «fetching the light from a church, visiting a church senior, and if the latter was not there, or was unable to attend the funeral, he was to find a substitute, to call a sexton, he was also supposed to go to a church, open it, take some light, a lamp full of liquid oil and wick, a cross and lanterns» [7, p. 214]. Here also existed certain differences, because a number of candles depended on a kind of the deceased: a child would need two wax candles as a rule, a married man would require «four candles, received for free», if someone wanted to take more candles, they had to pay for them; if a deceased was a man, a woman, a young boy or a young girl, they would take four candles, sometimes six or eight $[7, p$. 214]. Then the sexton would announce the funeral, tolling in the bell: «he would call in the morning, in the noon, and in the evening, as people were going to retrieve the body, then when people would come to the bell tower, and then while the dead body was being taken from the church and while people were taking it to the cemetery» [7, p. 214].

All elements and attributes of a funeral had a clear structure and people followed it closely. Certain things were placed the following way: a cross was placed near the deceased head, nearby they used to put a lamp, they would light a candle near the cross, on the table there always would lay some bread and, as Rev.M.Zubrytskyi noted down, in some cases, in particular in villages Mykhnivtsi and Bystre, people would put «a bowl with water and a shawl» beside bread [7, p. 214].

Therefore, a coffin with a body of a deceased was put in a certain place according to some rules, but bodies of children and elderly people were placed and situated differently. All the necessary elements and attributes were prepared and brought in by a certain person, who would put them in particular places afterwards, around the deceased.

A coffin as an element of a burial process was also of a significant scientific interest for Reverend M.Zubrytskyi. He described three types of coffins: «plain ones, smooth ones and gibbous ones» [7, p. 214-215]. The ethnographer himself did drawings of the two of them: smooth and gibbous ones. Ususally, «masters» made coffins themselves, if they knew how, or the coffins were made by certain skilled people. They were created from their own material or wood bought from carpenters. According to the ethnographer's notes, nobody was paid for making a coffin, but he was «fed and given a drink three times» [7, p. 215.]. In summer people made coffins outside, while when it was cold, they made coffins in the halls, passages and household buildings, where no one lived. On the bottom of a coffin people would put some hay, lay while linen, then it would be brought inside the house («hut»), people would light candles, and all the present ones 
would start praying.

While all the rituals of washing and dressing of the deceased were being performed until the moment when the dead was put into a coffin, his relatives, neighbours and other people, who would come to say farewell, would sit near the deceased. During the first night the psalm-book was read aloud customarily, people would also talk «about different things» and sing church songs. The master of the house had to treat those who were staying all night to alcohol (mainly «horilka») four times [7, p. 216].

In the day of the funeral people would take «crosses, two church banners, a felon, the Gospels and a small cross, as well as a litter» from the church [9, c. 216]. People would start crying and lamenting as soon as the procession would appear. People lamented for their relatives and close people: $a$ wife would cry for her husband, a mother would cry for her child, children lamented for their relatives, the same were doing sisters and daughters-in-law. According to what the ethnographer wrote down, people would start lamenting at least nine times: in the house for the deceased, who had died; when the candles were brought from the church; while the body was being washed; when there would come people to retrieve the body; while the coffin was being brought out; in the course of the burial procession and on the cemetery, while the coffin was being put into a grave [7, p. 224].

In her research, G.Sokil noted down, that Rev.M.Zubrytskyi described interesting observations concerning the usage and meaning of lamenting: «A wedding was no good without matchmakers, the same it was no good if no one cried for someone» $[4$, p. 400].

The scientist noted down different kinds of lamenting: lamenting the death of a husband, a mother, a child. People lamented death of different family members differently. A wife would lament her husband saying: «My husband, my master, my support, whom will I go to now, what will I do with small kids, left all by myself?... who do you leave me to?» [7, p. 224]; children would lament their mother: «mummy, our dear mummy, first you leave us, then we do not visit you, and then we cannot see you any more» $[7$, p. 225]; a mother would lament her child saying: «my sweet kid, you are still so young, but here you have to rot already; others' people kids still live, but my kid, so young, has already passed away; you are my delight, who will now come and talk to me, if you are no longer here» [7, p. 225], if a wife was not lamenting her husband's death, people would gossip about her, saying: «she had no regrets and sorrows at all, she had better spill at least one tear, wail just so that people did not speak ill of her» [7, p. 224].

After the funeral church service people would come to say farewell to the deceased: "a mother, brothers, sisters would kiss the face of the deceased, his hands, knees, and feet» [7, p. 216]. Also there was a custom for a wife to sprinkle the coffin with oats: «she would take some oats in her apron, go around the coffin three times against the clock and throw oaths over the coffin» [7, p. 217]. The ethnographer wrote that it was the way to say farewell to a master or a mistress of the house, their children, if they owned a whole household.

The ethnographer described one case, when people had put alcohol in a coffin, but in the majority of cases they never put anything in a coffin. The coffin was nailed and two young men would bring it out of the house and hit it to the threshold. The scientist described a situation, when the deceased was «accompanied by bread» in the villages Mykhnivtsi and Bystre: «someone from the family would take bread and put it on the inner threshold, on the outer threshold and in the yard on the coffin» [7, p. 216].

There existed a clearly-defined system of transporting of a coffin with the deceased. Rev. 0 . Zubrytskyi wrote that «a coffin was brought on a cart with oxen, and in winter they used sledges». The coffin was transported to the church, and it was being brought on a litter, and a kid's coffin was being brought by a couple of men.

On the cemetery there already was a dug-out grave, in the village Mshantsi it was usually done by an undertaker. His service cost one koron. According to Rev. 0. Zubrytskyi works, in the neigbouring villages «there was a queue for a grave» [7, p. 217].

The ethnographer also wrote that in some cases after the funeral the family of the deceased would invite the priest and some people for a dinner. This was customary only for well-off people, while common people rarely could afford it. After this dinner people used to say: «God bless the living and God grant the Heavens to those who have passed away» [7, p. 217].

Therefore, a final stage of the burial process consists of saying farewells to the body in the house of the deceased, a visit to a church and a sermon on the cemetery. Usually the body was transported on sledges or it was being brought in hands. Rev. 0 . Zubrytskyi defined a memorial dinner as an ending of a funeral.

Funeral repasts were served according to the church law and rules. Rev. 0 . Zubrytskyi wrote down, that there existed an ancient custom to visit the house of a person who had ordered a memorial ser- 
vice in the morning. All the village residents would visit the house in the morning, drink two small glasses of alcohol and go away saying the following words: «God bless the living and God grant the Heavens to those who have passed away». It was only after this, that the peasant, the master of the house, would invite some of them to come to the church and the memorial dinner afterwards. «Those who had been invited would go to the house, where they had drunk one small glass of alcohol before the priest came, then one more before the afternoon, and they would drink for the third time in the afternoon». A researcher from the Prykarpattia region 0. Drogobytska noted down that this very custom has been abolished on the initiative of the ethnigrapher in question himself [5, p. 130-131].

After the funeral people were following certain cautions and forewarnings, which were connected with possible negative consequences for people. Rev. 0. Zubrytskyi described main of these forewarnings. Majority of them were closely connected with calendar ritualism: «if there was a dead body in the house, there would be no carols in it» $[7, p$. 218]. However in the autobiography of the author one can read that "sometimes people would sing religious and church carols in the places, where earlier that year there had been a deceased, and this phenomenon had a special name» [10, p. 90]. Other superstitions and cautions included: «...the walls in house should not be neither washed nor rubbed with a yellow stone, especially of an elderly person had died there».., "one should not organize a wedding in a house, where there had been someone dead within a year, musicians should not play in that house, if there was an urgent need for a wedding, it had to be organized in the neighbour's house» $[7$, p. 218].

The scientist also described the burial process of a person who committed suicide. Local people told him of a case which happened in 1835, when «in the field in the village Mshantsy a man hung himself, his name was Guliv Matsko» [7, p. 224]. People's attitude towards suicides was very negative, so one of the villagers started hitting the corpse with a stick, asking; «Are you worthy of a cross?» [7, p. 224]. The body was dressed in his house, then it was put on a cart, but without a coffin, and they took him to Magura, which was a burial place in Mshantsi [7, p. 224]. The wife of the deceased was the only person to lead the horses, because «the cart did not obey anyone else» [7, p. 224]. On Magura people dug a grave, then put there a coffin with the dead body and put clay on it. The grave itself they covered with some branches [7, p. 224]. The ethnographer stressed that when someone was passing that place later, they would "put on more branches», that's why it created the present name «namet» $[7, p$. 224].

Rev. M.Zubrytskyi wrote about one accident, when a peasant from Khaschiv died in Limna because of alcohol [3, p. 555]. The local council passed a decision according to which his body was supposed to be «buried in one the Lomna's graves» $[10$, p. 3]. Having heard about this, the family of the deceased prepared «a cross and a coffin» in Khaschiv [10, p. 3], and brought them to Limna, but relatives and fellow residents from the village of the deceased stole the body and brought it back to Khaschiv [11, p. 555].

Ukrainian researcher S.Gvozdevych emphasizes, that «the live observations which are connected with death and funeral, and are provided by M.Zubrytsky, are very archaic», they constitute «preserved valuable knowledge about the ancient worldview of Boykos, their understanding of a close connection of humans and their surroundings, the flow of life and the place of a person in this world» [2, p. 395-396].

In conclusion, burial motives make up an important element of the family ritualism of the ethnographic group of Boykos, some can argue - even a crucial one. They were highlighted and analysed by a Ukrainian researcher M.Zubrytsky on the basis of his personal observations as well on surveys held among the locals of Starosambir and Turkiv regions. He created a so-called map of upcoming death on the basis of folk superstitions, proverbs, saying and dreams. He divided the burial process into three stages: pre-burial, burial and after-burial. All the stages were accompanied by appropriate rituals and elements, which were inalienable parts of the given process. In general all of these constitutes a picture of the burial process on people in the Western Boykos region, as well as points out particular features of the burial motives in some of the villages.

This problem remains up-to-date and requires a further thorough research including historiographical and source criticism information. 


\section{Джерела та література}

1. Кирчів Р. Етнографічне дослідження Бойківщини. К., 1978. 174 с.

2. Гвоздевич С. Михайло Зубрицький - дослідник сім'ї та сімейної обрядовості бойків // Народознавчі Зошити. 2008. N.3-4. C. 392-396.

3. Зубрицький М. Зібрані твори і матеріали у трьох томах. Т. 1: Наукові праці. Львів, Літопис, 2013. 456 с.

4. Сокіл Г. Із доробку Михайла Зубрицького - фольклориста // Народознавчі зошити. 2008, N. 3-4. С. $397-402$.

5. Дрогобицька 0. «Автобіографія» Михайла Зубрицького (1856-1919) як джерело до вивчення побуту бойків // Вісник Прикарпатського університету. Історія. 2010. Вип. 17. С. 128-133.

6. Дем'ян Г. Листи Володимира Гнатюка до Михайла Зубрицького // Записки НТШ. Праці секції етнографії та фольклористики. Львів, 1992, Т. ССXXIII. С. 295-308.

7. Зубрицький М. Похоронні звичаї й обряди в Мшанці і сусідніх селах Старосамбірського і Турчанського повітів // Етнографічний збірник. Т. 31-32, Львів, 1912, С. 211-226.

8. Зубрицький М. Міфи і вірування // Житє і Слово. Львів, 1894. Т. 2. С. 360-361.

9. Зубрицький М. Народній календар, народнї звичаї і повірки, привязані до днїв в тиждни і до рокових сьвят. (Записані у Мшанці, Староміського повіту і по сусїднїх селах) // Матеріали до українсько-руської етнології. Львів, 1900. T. III. С. 33-60.

10. Зубрицький М. 3 Староміського пишуть нам: як не раз чоловікови не поведеться, покаже ось яка приключка... // Діло. 1898. 23 марта (4 цвітня). Ч. 66. С. 3.

11. Зубрицький М. Зібрані твори і матеріали у трьох томах. Т. 2: Матеріали до біографії. Львів, Літопис, 2016. 616 с. 